Compare, Vol. 31, No. 1, 2001

\title{
What Poverty Does to Girls' Education: the intersection of class, gender and policy in Latin America
}

\author{
NELLY P. STROMQUIST, University of Southern California
}

ABSTRACT This paper discusses poverty and its implications for education in Latin America. It focuses on gender as a social construct that differentiates the impact of poverty. Through analysis of the interaction of gender, class and public policy, the paper examines aspects of national and global policy processes and educational disparities in society. It integrates micro-level descriptions of schooling with accounts of national government measures and wider social influences in relation to the education of girls.

\section{Introduction}

Latin America is the region of the world where the colonial mode of social organisation remained in force the longest-about 300 years since the arrival of the Spanish conquerors (1492) to the first wars of independence (1810). The social mix of subjugated populations (Indians), African slaves, and a dominant white minority that persisted was not conducive to the establishment of fair relations of social and economic exchange (Filgueira, 1983; Rama, 1983; Alcalde, 1999). Large holdings by wealthy descendants of the colonists and subsistence agriculture by the exploited and powerless peasantry still characterise the region. Over time, export-based agrarian capitalism led to the emergence of a powerful landed elite capable of using the power of the state to advance its goals (Grindle, 1986). With current trends toward economic competitiveness and the need to develop comparative advantages among countries, it is likely that Latin America will keep up its agro-industrial production, which does not bode well for the resolution of social disparities.

Poverty [1] increased during the 1980-1990 decade in Latin America, growing from 46 to $60 \%$ in urban areas and from 80 to $85 \%$ in the countryside. Extreme poverty increased from 22 to $27 \%$ in urban areas and from 50 to $52 \%$ in rural areas, according to statistics gathered by the Economic Commission for Latin America and the Caribbean, also known as CEPAL. In Brazil, the industrial giant of Latin America, 1990 urban poverty stood at 39\%, or 9\% above its 1979 level and 5\% above its 1987 level (CEPAL, 1994). More recently, from 1990 to 1997 , according to CEPAL, the proportion of poor households in Latin America dropped from $41 \%$ to $36 \%$. Not only are these gains small but the number of people who are poor increased from 136 million in the 1980s to 207 million in 1997 (CEPAL, 1998, p. 17).

Government expenditures on social benefits in the region remain largely regressive and will likely continue to be so in order to maintain investor confidence. Tax reforms 
and minimum wage policies have not been used to redistribute income to any significant degree (Oxhorn, 1998; Bejar, 1999; Acosta, 1999). Policies designed to deal with the structural causes of poverty and inequality, particularly through investment in education and health care, are sacrificed to the short-term priorities of maintaining economic equilibrium under the assumption that programs targeted to the neediest of the needy will buy the time necessary for the economy to produce more jobs (Oxhorn, 1998).

Although peasants and small agricultural producers continue to comprise the populations most seriously affected by poverty, in a number of countries the largest proportion of poor people are rural wage-earners, whether engaged in agriculture or working in other sectors, especially commerce and service (CEPAL, 1994, p. 24). The Latin American region has seen an increase in the share of income going to wage-earners with professional or technical qualifications, but not to less qualified earners.

In Latin America, thus, poverty is not a question of stubborn pockets of uneducated or untrained people but is rather inherent in the social and economic structure of the region. This structure is both the effect and cause of asymmetrical power relations between urban and rural areas, between indigenous peoples and mestizo subcultures, between men and women, and, of course, between the North and the South.

This paper deals with poverty and its effect on education in the context of Latin America. Its examination gives special attention to the question of gender, an important social dimension that greatly compounds the impact of poverty. It highlights the interaction between gender and two other important variables: social class and public policy, exploring the features of policies that emerge or fail to emerge to address serious educational disparities in society. To do so, this paper blends descriptions of school functioning at the micro-level with features and measures taken at national level through governmental action.

\section{Intractable Poverty}

At one level, poverty is essentially a normative concept, specific to each society. At another level, there is what has been called an 'irreducible core of absolute deprivation' comprising starvation, malnutrition, and visible hardship (Altimir, 1981). As is repeatedly stated in both academic and mass media reports, without much horror by now, in the world today about 3 billion people live on US \$2 a day or less and some 800 million people suffer from malnutrition.

What else do we know about the lives of the poor as a group? Very little, since beyond a few statistics we do not really have detailed studies of the poor. Nor do we know much about the rich, since they can easily avoid scrutiny. The fact that we know little of the lives of poor people greatly handicaps our understanding of the dynamic nature of poverty and how the lives of the rich and the poor intersect in functional and, often, inescapable ways.

In all countries of the world, we are making progress with key social indicators: life expectancy is going up, infant mortality is down, and illiteracy is also down. Yet poverty remains. What does this suggest in terms of the power of education as a tool for change? Could it be that we are ignoring those forces that indeed determine poverty? Probably we spend too much time defining poverty through statistical indicators while paying insufficient attention to the mechanisms and processes that create and sustain it. Further, currently favoured indicators of poverty do not tell us the distribution of income or wealth within the household (Kabeer, 1996). Poverty refers to what the poor lack, but their lack may be the result of a condition created or at best uncorrected by the upper 
and middle classes. Omnipresent as the concept of poverty is, it has not been sufficiently theorised in our understanding of how nations advance socially and politically and whether poverty represents an obstacle or is, on the contrary, a byproduct of unchecked 'advancement'. Work by feminist scholars question current initiatives by international organisations that call for 'poverty alleviation'. In their view, it is not alleviation that is needed, but instead drastic changes in power relations reflected in trade, the external debt, investments, and international development assistance (Townsend et al., 1999).

\section{The State and Education}

Most nation-states make an effective and yet paradoxical use of education. On the one hand, education is defended in official discourse as a social good open to all. On the other hand, public education is treated with neglect as budgets are held with a tight rein and the children of the poor receive the lowest quality of education. Unquestionably, the function of education as an easily-made promise to reduce poverty serves to foster confidence and stability in society in the meantime.

Now, in the day of the minimalist state, the emphasis is on short-term solutions. Opportunities for the poor are complemented by the state in its subsidiary role of providing certain public goods and income transfers targeted directly at the poorest in society. As public policies to ensure social welfare seemed to have reached a nadir, the market is supposed to determine the best set of opportunities for the poor (Oxhorn, 1998).

With the present form of globalisation (which emphasises commercial and technological features), the external debt, and structural adjustment programs, Latin America finds itself in an extraordinary moment of civil fragmentation. The growing social inequality has created a visible demobilisation of organised groups and has weakened the influence of labour unions, making it thus difficult for civil society to struggle for the expansion of citizenship rights (Oxhorn, 1998). In addition, austerity policies have brought reductions to sectors of governmental budgets with the weakest constituencies and yet the greatest potential for addressing the poor: education, health, social security and public housing.

Social expenditures in Latin America, of which education is traditionally a substantial part, decreased on a per capita basis by more than 20\% in 1977-1981 and again in 1982-1985 (de Janvry \& Sadoulet, 1993). The situation improved in the 1990s, when education as a percentage of the GNP rose in the region from 2.8\% in 1990-1991 to $3.7 \%$ in 1996-1997 and per capita expenditures in education rose from $\$ 251$ to $\$ 380$ in the same period for the population 5-17 years of age (CEPAL, 1998, p. 126).

\section{Schooling and Poverty}

Liberal ideology presents education as 'a system that can do much to further social mobility and redistribution of opportunities, while becoming an efficient mechanism of equalisation and social justice in accordance with meritocratic equality criteria' (Filgueira, 1983, p. 60). Liberal ideology also portrays public education as free and compulsory worldwide. This latter assertion is far from reality: it is seldom completely free as parents must buy school materials, books, and uniforms - a substantial expenditure for the poor-and rarely does an educational system in developing countries enforce school attendance.

Educational statistics for Latin America at first glance show an ideal situation with many countries evincing rates of nearly $100 \%$ in gross primary school enrolment. An 
examination of secondary school enrolment shows a much lower figure, comparable to that of Africa, which means that a large number of young people leave primary school, often without completing it. When educational statistics are contrasted between urban and rural populations, enrolment rates among the latter populations are consistently much lower (UNESCO, 1998).

When the statistics are compared by sex, the degree of access to schooling and retention among girls and boys does not appear to be very different. In fact, in several countries, aggregate data indicate that girls enrol in and complete primary and secondary schooling in greater numbers than boys (CEPAL, 1997; UNESCO, 1998). If one looks at crude indicators of educational attainment, in seven of nine Latin American countries the rates of primary school enrolment increased in favour of girls during the 1990s and repetition decreased more among girls than boys. In nine out of 10 countries, the proportion of girls that finished fourth grade stayed the same or increased, and in eight of those 10 countries the proportion of girls that finished sixth grade stayed the same or increased (CEPAL, 1997). So, a first impression is that girls are doing even better than boys in schooling.

While most countries rely on UNESCO statistics (which are themselves produced by member states), there is growing evidence that these statistics grossly underestimate the number of children out of school. These alternative readings of educational participation derive from household surveys, census data, or from computations carried out by UNICEF, whose concern for street children has led it to focus on out-of-school children and children in the labour force. Recognised as a major problem are the low rates of primary school completion. One of four major regional goals for 2000 (and unlikely to be met) was to attain at least $70 \%$ primary school completion (CEPAL, 1998). There are few educational statistics broken down simultaneously by sex and ethnicity. Those that exist (e.g. Post, 1998, for Mexico; Montero \& Tovar, 1999, for Peru) show a clear disadvantage for indigenous and particularly school-age girls living in poverty.

In the countryside, girls tend to enter primary school slightly older than boys and to leave at earlier grades. The low school participation rates are primarily a function of family or work obligations that render the individual unable to take advantage of available school offerings, but they are also due to a lack of school facilities. In rural areas, there are many single-classroom schools that usually serve only up to third or fourth grade (cases of Peru, Bolivia, Guatemala). The precise features and functioning of these 'multigrade' schools remains poorly documented in official statistics [2]. A study focusing on rural schools in Peru found that $90 \%$ of these schools operated in single rooms and that $37 \%$ had only one teacher, which suggests a high number of incomplete primary schools (Montero \& Tovar, 1999). In urban areas, public schools sometimes cannot meet the demand. Thus, one observes the common phenomenon of parents having to stand in line for long hours to ensure that their children will be enrolled before the school reaches its limit (cases of Brazil, Peru, among others).

Life in rural schools, for both students and teachers, tends to be harsh. A large number of these schools have no water, electricity, or sanitation facilities. Girls are frequently called upon to perform domestic tasks for teachers. Teachers in rural areas in Peru are usually younger and less experienced than urban teachers and not trained to deal with multigrade classrooms; their average stay in the poorest rural areas is about two years (Montero \& Tovar, 1999). The school year is much shorter than officially planned due to absences by both teachers and students. The learning hours per day are also shorter than they should be as time is spent in tangential activities such as long breaks or preparations for various extra-curricular events (Hornberger, 1987; Montero \& Tovar, 
1999). While boys and girls are equally affected by these practices, domestic and school factors combine to produce more women than men without schooling or with incomplete primary. In the case of Peru, data for 1997 show that while $28 \%$ of rural men $15-24$ years of age have either no schooling or incomplete primary, the figure reaches $39 \%$ in the case of women (Montero \& Tovar, 1999, p. 7).

At the macro-level, there exists a strong tie between the inequity in educational capital distribution and the inequality of income distribution inequality (CEPAL, 1997). In other words, population groups tend to have levels of school attainment proportional to their income. Most poor and extremely poor children in the region have parents with less than nine years of schooling (72 and 96\%, respectively) (CEPAL, 1997, p. 143). On the other hand, as Rama (1983) has observed, in Latin America education has expanded more extensively than any other social good but this development has been 'inconsistent with the opportunities afforded by the social order in respect to income and participation in power' (p. 24).

The assumption of causality between poverty and education may be misread. It is not that parents are poor because they have no education; rather, they have no education because they are poor. Moreover, it appears that education in Latin America increasingly needs more years of schooling to be marketable in the labour force. According to studies by CEPAL (1994), it is 'necessary to have 10 years of schooling, and in many cases complete secondary to have an income above the poverty line' (p. 31). The level of education needed for a well-paying job will probably increase because globalisation trends in the labour force build upon differentiated schooling: university-level education especially with technical and scientific degrees for the highly-paid occupations and low levels of schooling for the provision of semi-skilled services in low-paid jobs.

\section{Poor Families and Schooling}

Public education at primary and secondary levels, not being free beyond tuition and the provision of some textbooks, represents high expenditures for low-income families. In principle, all families recognise the importance of education. Poor families try to give their children at least several years of education, but in the end withdraw them early. Since the children of the poor attend low-quality and incomplete primary schools, they tend to withdraw from school without having reached a solid literacy threshold; thus, many of them regress in their reading and numeracy skills.

For poor people, education means a trade-off, usually between obtaining food and going to school. From the perspective of the indigenous groups in rural areas, it might mean 'having to sell chickens to buy notebooks' (CEIMME, 1995). Having children go to school also means losing an income-earner. For instance, working in the tobacco crops of Nicaragua, adults earn US \$11 dollars every two weeks; children are often paid half the salary of an adult, but poor parents still need that income (Havelin, 1999). Further evidence from Nicaragua illustrates the effect of deteriorating economic conditions for poor people in the late 1990s. Many poor Nicaraguan families found themselves with no disposable money for such public school expenses as pencils, notebooks, uniforms, shoes, exams, and even fees for security guards (Havelin, 1999). With an annual per capita income in Nicaragua of about US $\$ 340$ in 1992, a family with two children in primary school and two in high school would need to pay some $\$ 60$ per year, over one-sixth of its total income (Havelin, 1999, p. 27, citing Copling).

Low educational attainment does not always occur because children are taken out of school. Often, it happens because the children fall behind in their studies, as in cases 
when members of the family fall ill and children have to help in their care, or when the children themselves get sick and parents have to take them out of school to pay for medicine. Students from poor backgrounds, especially in cases where father abandonment is coupled with poverty, also develop serious emotional and social needs. Children of rural parents sometimes lack birth certificates and without such papers they have a difficult time enrolling in school (Montero \& Tovar, 1999). Teachers of the poor often report having students who come to school tired, withdrawn, or overly aggressive. In many urban centres, it is common for teachers to find children who show up unannounced on the school's doorstep, their educational history a mystery, or cases where they leave with little or no notice, never to be seen again. These problems affect both girls and boys.

\section{Teachers and Poor Children}

It is sometimes forgotten that teachers of poor children are often poor themselves. In Bolivia and Ecuador, 65 to $70 \%$ of the teachers live in either poor or vulnerable homes (CEPAL, 1998) [3]. In Mexico and Paraguay, 35 to $40 \%$ of teachers live in vulnerable homes (CEPAL, 1998).

For many years, one of the strongest conflicts regarding public education has concerned the salary of teachers who, compared to people in occupations with similar years of schooling, end up earning much less (CEPAL, 1998) [4]. In the past seven years, Latin American teachers have received significant raises, as about $70-80 \%$ of the (modest) increase in educational budgets have gone to better salaries for primary and secondary school teachers (CEPAL, 1998). Yet, the fact remains that teachers' salaries are seldom sufficient to have comfortable lives.

The public/private divide in education has significant consequences upon teacher salaries and consequently on the quality of education that is provided to poor as well as non-poor students. On average, private teachers earn more than public school teachers in primary schools by 10-20\%; this gap increases to about 30-45\% in secondary schools (data for Brazil, Chile, Costa Rica, Ecuador, and Paraguay; CEPAL, 1998). The wage differential between public and private is substantial enough to foster a migration of the best qualified teachers toward the private system, thus augmenting the difficulties experienced by poor children. According to the World Bank (1993), one-third of the region's teachers lack professional certificates or degrees. It is well known that these teachers are usually assigned to work in rural areas, thus compounding the negative effects of poverty among rural children.

In comparing the salaries of teachers in Latin America with those of OECD countries in terms of the national 'level of effort' (defined as the teacher's salary as a percentage of GNP per capita), it has been found that Latin American teachers receive a share comparable to teachers in Northern countries (i.e. about $1 \%$ of the GNP). This point is of interest because it suggests that in Latin America it is the countries' level of poverty which creates difficult conditions for their teachers (1995 data, CEPAL, 1998).

In short, poverty not only prevents poor children from gaining access to schooling, but it imposes limits on the number of years of school attainment. The state contributes to this situation by the provision of incomplete primary schools and inexperienced teachers in the countryside. 


\section{Poverty and Women}

Feminist perspectives assert and have empirically demonstrated that gender is an element of social relationships that operates at multiple levels, affecting everyday interactions, public institutions, work, and the household. The consequences of gender distinctions are reflected in political, economic, and cultural spheres. Within the cultural sphere, gender asymmetries are expressed and reproduced through definitions of femininity and masculinity (including prescribed types and range of emotions) supported by such mechanisms as ideology, sexuality, language, law, schooling, and the mass media, among many others.

Feminist perspectives maintain that gender is a social marker that affects men and women. They also maintain that it affects all women negatively regardless of social class and ethnicity. Rather than argue which social marker is the strongest discriminant, feminist views are sensitive to the effects of the interaction of these markers and do not underestimate the specificity of gender.

Some societies defend gender differences on the basis of their own cultural values and preferences. But as Kabeer (1996, p. 16) notes, 'culture has profound material consequences, not only in shaping priorities and perceptions ... but also in shaping allocative behavior and practice'. For instance, in societies influenced by fundamentalist religious beliefs, culture tends to create norms that restrict women's physical and mental space. Across social classes, girls tend to have less physical mobility than boys and thus less freedom to move to larger towns or other countries to continue their education. Norms of femininity and masculinity restrict their choice of fields of study and later their choice of occupations. Women receive less remuneration for their years of education than men. Finally, women tend to aspire to political positions of less prestige and responsibility than men.

Among poor families, especially those in the rural areas, the sexual division of labour is of fundamental importance. Because girls in poor homes and in rural areas conduct the bulk of the domestic chores, parents perceive school knowledge as moving their daughters away from essential tasks. In communities lacking basic domestic facilities (e.g. electricity, potable water, sanitation facilities, rubbish collection), girls and women assume these chores. Since the poor have less possibility of regular medical attention, typically women and girls must assume these services, which usually translate into special diets and rest for the ill members of the family. In indigenous areas of Latin America, it is women who traditionally weave the clothing for their families. This is an activity that demands considerable skill and time. Its direct and indirect consequence on the availability of rural girls for schooling has not been analysed.

Poverty, in the Latin American context, also reflects itself in migration, from rural areas to major cities within the country or to foreign countries. Challenged by poverty, the cultural norm of women's restricted mobility has weakened. A major reason women migrate is to improve the quality of life for themselves and their families. In some cases, this is accomplished by taking menial jobs, in which case education levels are of relative unimportance. In fewer cases, women are forced to engage in prostitution, which, again, has no particular educational correlate.

While human capital assumes that salaries are a good measure of productivity, there is mounting evidence that women are given lower salaries than men for similar years of schooling. It has been asserted that women earn less because they are in fields that are less important and thus less well remunerated, but this is itself a reflection of societal values that discriminate against women's work. Another argument explaining these 
differences has been that women tend to work fewer hours than men, but a study comparing salary levels in terms of value per working hour found that women in urban areas earned between 66 and 80\% of men's salaries with the same levels of education in eight of 10 countries analyzed (CEPAL, 1994, citing 1992 data).

Education certainly helps women, but studies conducted by CEPAL several years ago found that, on average, a woman needed four more years of education than a man to earn a comparable salary. It should be observed that this statistic was presented at that time as an interesting finding rather than as a major social problem. Education is statistically associated with socio-cultural background and with income. The first association (sociocultural background and education) indicates that education is not completely meritocratic; the second (education and income) suggests that education nonetheless is an important tool for social mobility. Competition in the labour market is imperfect and, thus, women need to be protected by labour legislation if their education is to be instrumental to their advancement.

While far from a perfect correlation, higher levels of education generally lead to higher levels of income for women. On the other hand, improvement in the economic well-being of women does not necessarily translate into greater autonomy and decision making in the domestic sphere, especially concerning decisions over their own body. This disjuncture suggests that higher levels of schooling are not a sufficient ingredient to foster autonomy and self-assertiveness in women. Thus, it would appear that there is a need to work on the content and experience of schooling to make education more responsive to women's feelings and practice of empowerment.

Highlighting the connection between poverty and women's education, the following points can be made:

(1) Poverty is a strong manifestation of inequity in society but it is not the only one. As Kabeer succinctly puts it, 'Not all women are poor, and not all poor people are women, but all women suffer from discrimination' (1996, p. 20). Gender differences operate in extremely important ways and serve to create and sustain poverty in society.

(2) In Latin America, men and women do not seem to show drastically different rates of enrolment and educational attainment compared to other regions of the Third World, but when analyses are made considering ethnicity and high levels of poverty, Latin American women are certainly at a disadvantage compared to men in terms of access to and completion of schooling.

(3) Owing to the current course of technological development and the presence of foreign firms with a greater sense of gender equality in many developing countries, some new opportunities are being opened to women, but gender inequity is not going away; it is being reinscribed in new ways. For instance, more women are moving into low-tech jobs regardless of social class.

(4) In debating the demands for greater access by girls to schools, it is usually forgotten by policy-makers that what is actually learned in school tends to be quite gendered. Gendered knowledge is acquired via the formal and the hidden curriculum, conditions that exist in all schools regardless of the quality of schooling. There is very little research of an ethnographic nature documenting the lived experience of girls and boys in Latin American schools. The comments by Longwe, reflecting on her experience as a teacher in African schools, seem equally applicable to Latin America. She states: 
Women with less schooling are likely to develop a clear perception of the asymmetries in the gender division of labour. The nearer they are to the poverty line, the less they can protect themselves by exploiting the labour of women even poorer than themselves. Being unschooled, they cannot rise by becoming honorary males. (1998, p. 26)

(5) Contrary to the argument that it is quality of schooling that causes poor girls to drop out (see, for instance, O'Gara et al., 1998), poor girls are much more likely to leave school because domestic responsibilities at home do not allow them the free time necessary for schooling and because poor families must rely on the labour of their children from early years. Poor parents rarely know enough of what goes on in schools to be able to judge their quality. If quality were a factor, this would affect boys more than girls, since it is the schooling of boys that tends to be seen as an investment. In some cases, the 'relevance' of what is learned in school may be contested by rural families. The school's lack of relevance, however, is not prominent in decisions to take girls out of school.

(6) It is incorrect to see women as merely one among several disadvantaged groups, next to rural, unemployed, street children, handicapped, etc. and to limit gender policies to the plight of poor women. This characterisation ignores the gender dimension of disadvantage and sees it as a less ingrained and pervasive social distinction.

(7) It is important to move away from identifying symptoms that affect the participation of girls in schooling and try, instead, to understand and correct the underlying causes of gender asymmetries in power. This implies a substantial use of feminist theory to move toward an understanding of the fundamental and interrelated causes of gender-based discrimination in society and an examination of schooling as a site where gender asymmetry is reproduced and yet may also be contested.

\section{The Role of Governmental Policies}

Education is considered a universal right in the UN Declaration of Human Rights. It is also a legal obligation since there is a convention that sustains this principle, the 1989 Convention on the Rights of the Child. Surprisingly, no state in the Third World has been sued by its citizens for failing to provide schooling to children, a right also enshrined in most constitutions [5].

In an ideal world, economic policies that protect fair wages and fair terms of trade for products and services would obviate the need for special measures to ensure the minimum social welfare of citizens. In other words, in a fair economic world, social policies would be redundant. But if the world is not ideal, compensatory policies and their concomitant programs for the poor are needed.

The Economic Commission for Latin America and the Caribbean has long recognised the importance of educational equity. But educational equity is construed, first and foremost, as the equal distribution of schooling across social classes (proxied through income levels); a distant second in the concern for equity are urban/rural differences (see, for example, the arguments developed by Iglesias, a former executive director of CEPAL [Iglesias, 1981]; see also Martin, 1997). In the 1990s, shortly before the Fourth World Conference on Women, CEPAL produced its second plan on gender and education (following one enacted in 1977). This plan recognised 'insufficient opportunities for large sectors of the female population to enter and stay in the education system; maintenance of school curricula and teaching practices that limit women's opportunities 
to participate in society and reinforce the lack of equity between women and men' (ECLAC, 1995, p. 23). The plan proposed a series of 'strategic actions' to be adopted by governments. It is not precisely known to what extent this regional plan has become reality. What is known is that while all Latin American countries have by now governmental units in charge of women in development, these are clearly understaffed and underfunded to comply with their mandate.

Two observations can be raised on the relation between equity and social class. First, Latin America indeed faces a serious problem of distribution of schooling according to income. In Brazil, the country with the highest income disparity in the region, $65 \%$ of the school-age children in the top income-per-capita quartile complete eight years of schooling by age 16 in contrast to only $14 \%$ in the bottom quartile (CEPAL, 1994, p. 89). CEPAL (1997) predicts that in Brazil by the year $200040 \%$ of lowest income quartile in urban areas will never complete fourth grade, so conditions exist to perpetuate extreme poverty. In Costa Rica, where income distribution is one of the most equal in Latin America, educational inequalities are still quite visible: $84 \%$ of young people in the highest income per capita quartile in urban areas complete eight years of schooling by age 16, in contrast with only $40 \%$ of those in the bottom quartile (CEPAL, 1994, p. 89).

Second, the official discourse about education is still cast in apolitical terms, leaving the ideological function of schooling unquestioned. While both global agreements (e.g. the Platform for Action emanating from the Fourth World Women's Conference in Beijing, 1995) and regional documents (e.g. ECLAC, 1995) recognise the need for intervening in school curricula and teacher practices to correct women's subordinations, few governments in Latin America have acted on these recommendations, much less altered the ways the hidden curriculum functions. Countries with large ethnic and rural populations, and thus with substantial poverty, have not engaged in these forms of educational transformation; these countries include Mexico (Gonzalez \& Villaescusa, 1998), Peru (PROMUDEH, 2000), and Guatemala (Stromquist et al., 2000), although Ecuador seems to be making inroads (GEO \& REPEM, 1999). The belief in the neutrality of education is so widespread that it permeates even the demands for schooling of low-income groups, who also tend to be acritical of the gendered messages the school transmits. Some indigenous NGOs, notably those in Ecuador, Guatemala and Mexico (Chiapas), have contested the negative portrayal of native peoples, but even they remain silent regarding the gendered content of the schooling experience.

Several Latin American governments have enacted policies to address the question of equity. These policies include:

- Increasing subsidies and resources to schools for their day-to-day functioning (being attempted in Bolivia, Chile, Mexico, Peru).

- Lengthening the school day in schools that perform poorly in achievement tests and increasing the number of hours per week of those attending basic and intermediate education (carried out in Bolivia, Chile, Colombia, Costa Rica and Peru).

- Transferring (presumably trained and credentialled) teachers to critical areas.

- Expanding school meals and scholarships (Chile).

- Developing field-oriented schools in various disciplines (scientific, technical, artistic) (CEPAL, 1994, p. 118).

As can be seen, all of these measures seek to increase the effectiveness and efficiency of schools. Yet they are gender-blind, focusing primarily on poor communities and their schools. To undertake analyses that examine the distribution of education only by income levels and to fail to look at finer studies that consider the compound effects of 
gender and ethnicity is tantamount to considering social class as the key determinant of social outcomes and to ignore the role of ideology (regarding gender, ethnic and 'racial' differences) in the formation of social distinctions. The disregard of gender and 'racial' variables has proved a major weakness in current theories of national development and social change.

Through support to a few countries, particularly Guatemala, Bolivia, and Paraguay, several bilateral and multilateral agencies are acting to improve the conditions of girls' education (Cortina \& Stromquist, 2000). It is important to remark that it is girls' and not women's education because international support tends to be concerned almost exclusively with the basic education of girls. When dealing with adult women, agencies give priority to reproductive health issues and local political participation, and, to a lesser extent, to income-generation skills. One of the few gender-focused compensatory efforts (not a policy) was attempted in Guatemala under USAID auspices in 1993-1996. Conducted as an experimental project, scholarships were found to increase the attendance of girls in rural areas (see Stromquist et al., 2000). It should be noted that many of the governmental policies on gender often exist through the support of international development agencies. So in fact, such policies are not nationwide efforts but rather small projects, in many instances operating as pilot projects [6].

Paradoxically, today gender equity is an accepted term and focus in public policy. There is new legislation on such issues such as domestic violence, rape, and representation quotas favouring women candidates for public office. There are also numerous initiatives to foster awareness of the use of contraceptives and of the spread of sexually transmitted diseases. But in the area of formal education, there still prevails the narrow vision of looking at it as the provision of access for women, particularly to basic education. Schooling as a fundamental site for the formation of gender ideologies passes unquestioned and thus governments do not seek to reform its overt and hidden curriculum or to train teachers for non-sexist and anti-sexist practices [7]. In fact, the first step in any kind of public policy development, the procurement of data, is missing. There is a serious need to acquire more data disaggregating gender by social class, ethnicity, and residence (rural/urban).

Two fundamental challenges to the successful design and implementation of public policies on gender come from within and outside Latin American countries.

\section{The Challenge from Within: a bifurcated educational system}

In Latin America, any enactment and implementation of educational policies to serve the marginalised social groups will be difficult. As Rama (1983) argues, in societies whose historical characteristic was the exclusion of the broad masses from education, and where there is radical socio-cultural discontinuity between them and the elite, the middle classes attach themselves to the upper class as a means of defending the small spaces at their disposal and tend to build up educational systems with the same peculiar features of social selectivity and ascriptions that characterised the traditional oligarchies' (p. 35).

In concrete terms, the imitation of upper-class norms has resulted in the existence of private schooling for groups who aspire to social mobility or who seek to keep their high status. In all countries of Latin America, there is a bifurcated educational system, with private elite schools catering to the wealthy classes and to middle-classes seeking higher mobility, and public schools serving mostly poor children. The higher-quality academic circuits function in a very closed manner, with entry usually beginning from pre-school in private and very selective institutions and moving into similarly exclusive universities 
[8]. The continuous deterioration of the public school system (persistently subjected to very low resource allocations) has also led to the emergence of non-elite private schools, attended by children of middle- and low-income families. De facto, this means that public schools in Latin American increasingly serve poor children whose families have low leverage on the political system.

Does this mean that states will not engage in equitable educational policy-making? No. What it means is that many policies will acquire symbolic rather than material character. It means also that policies will have a very narrow focus and will be short-term. Unless the heterogeneity of the colonial past is resolved through a profound social pact, such policies can be expected to play only a weak role in the reconfiguration of society.

\section{The Challenge from Without: missing global equity}

Attempts to solve the problem of poverty cannot avoid dealing with structural factors; otherwise, we will continue indefinitely the pretense of taking poverty seriously [9]. To 'alleviate' poverty, several Latin American countries have established emergency funds and social investment funds in areas of health, education, and water and sewage systems. These funds, which have been established at different times, from 1971 onwards, have had a 'limited role in launching long-term anti-poverty programs' (CEPAL, 1994, p. 114).

To address structural poverty, certain changes are needed in the global market and would be complementary to other government sectors at the national level. In the case of Latin America, as is true for several African and Asian countries, the terms of trade that render agricultural products increasingly less valuable compared to technology-rich products place poor countries in a losing battle for the creation of national wealth. The burdens of excessive external debt further render national budgets very weak in social welfare (Alcalde, 1999; Acosta, 1999). Unequal terms of trade create differential living standards across countries; with globalisation, emigration of highly educated personnel out of the Third World is facilitated by constant demand in major industrial countries to enhance their industrial competitiveness [10]. In addition to improving the terms of trade, DAWN, a major global feminist NGO, proposes: changing the taxation system and making its functioning more effective, engaging in agrarian reform, and fostering the existence of NGOs as active counter-hegemonic elements of civil society (DAWN, 1995).

For compensatory educational policies to succeed, it is essential to affect other areas of the economy, particularly those pertaining to employment and health. Making the design of public policy even more difficult is the realisation that labour-intensive growth strategies will benefit poor women only if efforts are made to address the sexual division of labour at home and in the marketplace (Kabeer, 1996, p. 20). If no other social mechanisms for equalisation obtain, problems of over-education, devaluation of educational credentials, and competition for education 'goods' emerge (Filgueira, 1983). If educational policies do not remain in place until a stable solution is attained, good efforts may be short-lived. One case in point is Nicaragua: illiteracy before the Sandinista revolution (1979) was at 54\%. With the subsequent literacy campaign it was supposedly reduced to $25 \%$, yet estimates in 1996 put it back up to about $50 \%$ (Havelin, 1999). 


\section{Political Action from Civil Society}

In trying to explain why some oppressed groups rebel to secure better conditions for themselves, Moore observes that 'there is no guarantee that exploitation, or just plain misery, will somehow secrete its own antidote ... Human beings have to create their own moral standards of condemnation and their own forms of collective action to change such situations' (1978, p. 457).

The first ones to take on the politics of poverty seriously will thus be the poor themselves. This requires that groups within civil society must be organised to put pressure on the state to implement corrective public policies and to engage in selfsupport initiatives. What Moore calls 'moral standards of condemnation' in my view implies a very strong knowledge foundation. One has to know the conditions that affect oneself as a poor person or poor group and the conditions that more privileged groups enjoy in order to develop some awareness of inequality and thus of injustice.

It has been remarked by some political observers and several feminists (activists and scholars) in the region, that the transition toward democracy in several Latin American countries was dominated by political parties and elite actors, a condition that, as a whole, has retarded the development of non-governmental organisations and grassroots groups (Oxhorn, 1998). In several cases, notably Chile and Argentina, women have been incorporated into the state bureaucracy but under the state's parameters that women should be professionals and technical experts, not advocates of feminist issues. International support for the more democratic states has been increased by withdrawing and transferring support from NGOs, including the women-led NGOs.

Overall, the women's movement in Latin America has had a limited impact on gender equity policies for formal systems of education (see Cortina \& Stromquist, 2000, for an account of recent gender equity policies in the region). The work of women-led NGOs has typically concentrated on the education of adult women. Their efforts have addressed educating them in such issues as reproductive health, labour conditions and legislation, human rights (particularly domestic violence and rape), and political participation at local and national levels. The contributions that women-led NGOs have made to the development of new forms of citizenship among women are impressive. Surprisingly, however, their work has not questioned the ideological nature of the formal education system to the same degree that they have attacked the more visible welfare policies. A regional network, Red de Educación Popular entre Mujeres de América Latina y el Caribe (REPEM), has advocated the development of non-sexist education in the schools since 1990. This network has been able to conduct several training workshops for NGO personnel and teachers throughout the region and has fostered greater gender consciousness through short-story contests. However, its reduced funding has not allowed it to have a major impact on formal school systems.

The potential for women-led NGOs to address formal education is significant if we consider the multi-class composition of the feminist movement and its many organised groups. As Rama observes, 'Education contains in embryo a principle of social homogenisation and meritocratic selection, provided that it is itself effectively homogeneous, of scientific quality, and capable of developing personalities with independent criteria' (1983, p. 38). A major challenge for the feminist movement is to become more aware of formal education as a major political terrain and become more active in it. 


\section{International Co-operation and Gender-sensitive Education}

International agencies, with the collaboration of many NGOs, took a very positive step when they endorsed universal primary education, crystallised later in the Education for All Declaration, signed in Jomtien, 1990. While the declaration acknowledged that two-thirds of the illiterate adults were women and stated among its key strategies that 'the most urgent priority is to ensure access to, and improve the quality of, education of girls and women and to remove every obstacle that hampers their active participation' (Interagency Commission WCEFA, 1990, p. 45), the governmental and donor agency action that ensued was not sufficient to meet either quantitative or qualitative goals (Torres, 2000). The World Education Forum, which met in Dakar in April 2000 to renew commitment to EFA, reiterated commitment to formal education for women, stating as a (repeated) goal: 'eliminating gender disparities in primary and secondary education by 2005 , and achieving gender equality in education by 2015, with a focus on ensuring girls' full and equal access to and achievement in basic education of good quality' (WEF, 2000, p. 2). It remains unclear how the new timelines will enable countries to satisfy commitments not honoured in the past.

Literacy and adult basic education programmes, which are those most likely to be needed by the poor, have received very little attention. Weakening the possibilities for transforming the educational situation confronting poor women is the fact that structural adjustment programmes have also reduced national education priorities to cover only basic education and only for ages 7-14 years of age. This has been observed particularly in the case of Brazil, the Latin American country with the largest number of illiterates (Di Pierro, 2000). Agencies such as the World Bank, which play leading roles in shaping educational policies in the Third World, have adopted a view that illiteracy is a problem of the past and that as long as we keep making younger generations more able to go to school, illiteracy problems will disappear.

As to the policies pursued by international agencies, it is worthwhile to recognise that very few studies have been made of their actual effects. The expansion of pre-school in Brazil since the 1980s through the intense support of UNICEF offers important lessons. Through the use of census and household survey data, Rosemberg (2000) notes that approximately $86 \%$ of the pre-school expansion in Brazil took place through the hiring of women teachers who had only primary education, and were thus saddled with weak preparation and low salaries. She also found a large group of students of ages 7 to 9 in pre-school (11\% by 1993), most of whom were black and poor. Rosemberg interprets this over-age preponderance as a reflection of the length of time they are retained in pre-school. Remarking that the pre-school women teachers receive low salaries and that the black children are being placed in dead-end schooling, Rosemberg concludes that there is 'an intricate game of subordination of class, race, and gender' going on through these 'low-cost compensatory educational programs'. She observes that a programme with a low financial cost may come with a high social cost.

\section{Conclusions}

Poverty is endemic in Latin America and affects a large segment of its population. While the region is more democratic than in the past, it has also become more unequal (Oxhorn, 1998). With globalisation, there has been a revival of the importance of education; this education is framed in terms of economic competitiveness, not social justice. In fact, 
however, the need for highly trained technical personnel may not create the atmosphere required to increase attention to poor and disadvantaged groups.

There continues a tendency to look at educational systems as self-contained, focusing on access to and completion of basic education, or as a means to achieve economic competitiveness, giving priority to the question of efficiency over equity. After years of considerable neglect, education in Latin America is emerging as a major policy concern (see, for instance the work of the Inter-American Dialogue, reflected in Puryear, 1997). This concern, unfortunately, is framed in terms of effectiveness and evinces a narrow definition of quality. By no means is quality being defined in terms of developing civic understanding in youth and adults, not to mention understanding of inequities and inequalities in society. Under such circumstances, it must be concluded that new educational policies emerging in Latin America are genderblind.

Problems of access and attainment are still present and affect mostly rural areas, most of which are inhabited by groups of Indian or African (in the case of Brazil) descent. Much work remains to provide them with complete primary schools of good quality. Nonetheless, the fundamental educational problem for women, whether poor or rich, concerns the unquestioned, non-problematised gender-biased nature of schooling. Educational statistics focusing on access are not only likely to be overstated but they fail to capture the dynamics of discrimination that girls and women continue to face in the educational systems of their respective countries in terms of their everyday experience and what is learned in school. In this regard, more studies based on qualitative research methods are urgently needed.

Governmental policies in education have tended to respond to demand forces, albeit mostly urban, for greater access to schooling. These responses have not met the ambitious quantitative goals set by Jomtien but have permitted greater participation by the poor. Simultaneously, the expansion of schooling has not been accompanied by explicit recognition of the underlying factors that create the disadvantage in access and completion of rural and indigenous women, and has not been characterised by interventions to modify significantly the gendered nature of textbooks, teaching, and the overall schooling experience.

Public policies face particular tensions in the solution of the education of poor girls. Access, completion, and quality goals for the schooling of girls remain unfulfilled. While compensatory policies focusing on the poor make sense, as they prioritise the group most in need, policies that focus on poor girls have the effect of circumscribing gender problems only to the poor. Further, policies that concentrate on school access and completion, while reasonable from the perspective of social equality, leave the school untouched as a venue where undemocratic forms of femininity and masculinity are created and sustained.

Countries suffering structural poverty, such as those in Latin America, require a more comprehensive prescription. Education, as a form of socially legitimated knowledge, certainly helps individuals to obtain better jobs and higher salaries. But in bifurcated educational systems such as those characterising the region, education brings disproportionately higher rewards to the wealthier social classes. For schooling to make a substantial difference in the lives of poor women, not only does it have to be redesigned but it has to be accompanied by measures in other sectors of social and economic life, some national and some international. 
Correspondence: Nelly P. Stromquist, Rossier School of Education, University of Southern California, Los Angeles, CA 90089-0031, USA.

\section{NOTES}

[1] There are many ways of defining poverty. According to Kabeer (1996), two common conceptualisation s of poverty are: (a) as a means, in which income levels are used as key proxies for well-being, and (b) as an end, which concentrates on the actual satisfaction of basic needs, including educational attainment. CEPAL defines poverty as the income below the poverty line, which in turn is defined as the amount of income relative to the 'basic food basket' required to cover nutritional needs, taking into account consumption habits, availability of goods and relative prices, plus the resources required for the satisfaction of non-food needs (CEPAL, 1998, p. 51). It defines as indigentes or people in extreme poverty 'those whose income is so low that it does not cover even nutritional expenditures' (CEPAL, 1998, p. 51). Perhaps because of different formulas used to measure poverty, it is not uncommon to find inconsistent statistics (sometimes produced by the same agency) concerning the poor and the extremely poor.

[2] A welcome effort to address the need for greater understanding of multi-grade schools is the cross-country study being coordinated by Angela Little (1999) and her associates.

[3] CEPAL defines vulnerable households as those whose total incomes are between 0.9 and 1.25 times the value of the poverty line (CEPAL, 1994, p. 12).

[4] Teachers earn less than other professionals with equal years of schooling in all Latin American countries, with the exception of Costa Rica (CEPAL, 1998).

[5] In Brazil, where basic education is protected by its latest Constitution, there was an unsuccessful attempt by an NGO to sue the government in 1994.

[6] An example of the tendency to confuse externally-funded projects with national policies is reflected in King and Hill, 1993.

[7] Following Streitmatter (1994), we define non-sexist teaching as that attempting to question stereotypes and representations of men and women in different spheres of society, while anti-sexist teaching would be those efforts more proactive in nature seeking to develop an alternative view of society, with both men and women in equally important and valued roles and functions.

[8] There has been a tendency by the elites to send their children to public universities that enjoy excellent reputations, in countries such as Brazil, Mexico and Chile. This situation is changing, however, with the emergence of high-prestige new private universities; these are also expensive but their high fees create a selective social environment that wealthy families prefer.

[9] Helder Camera, a Brazilian bishop who worked with the poor of Northeastern Brazil for many years, is reported to have stated, 'When I give food to the poor, they call me a saint; when I ask why the poor don't have food, they call me a communist' (Selbin, 1998).

[10] Brain-drain is increasing at a substantial rate. Not only are countries losing their people trained in science and technology, as medical doctors and computer engineers go North to secure better jobs, but also people trained in less technical fields or with little education leave to get menial (but higher paid) jobs abroad.

\section{REFERENCES}

Acosta, A. (1999) La increible y triste historia de America Latina y su perversa deuda externa, Socialismo y Participacion, 85, August, pp. 29-48.

Alcalde, J. (1999) Desarrollo, subdesarrollo y decadencia social, Socialismo y Participacion, 85, August, pp. 9-25.

Altimir, O. (1981) Poverty in Latin America. A review of concepts and data, CEPAL Review, April, pp. 65-91.

Bejar, H. (1999) Deuda externa y deuda social: legitimidad y derechos humanos, Socialismo y Participacion, 85, August, pp. 49-75.

CEIMME (1995) Mujer Indigena y Participacion Politica (Guayaquil, Centro de Estudios e Investigacion sobre el Maltrato a la Mujer Ecuatoriana).

CEPAL (1994) Social Panorama of Latin America 1994 (Santiago, Comision Economica para America Latina y el Caribe).

CEPAL (1997) Panorama Social 1997 (Santiago, Comision Economica para America Latina y el Caribe). 
CEPAL (1998) Panorama Social 1998 (Santiago, Comision Economica para America Latina y el Caribe). Cortina, R. \& Stromquist, N. P. (Eds) (2000) Distant Alliances: gender equity policies in education in Latin America (New York, Garland Publishing).

DAWN (1995) Rethinking social development. DAWN's vision, World Development, 23(11), pp. 2001-2004. DE JAnVry, A. \& SAdoulet, E. (1993) Market, state, and civil organizations in Latin America beyond the debt crisis: the context for rural development, World Development, 21(4), pp. 659-674.

Di Pierro, M. C. (2000) Public policy and adult education for women in Brazil, in: R. CortinA \& N. P. Stromquist (Eds) Educational Policies for Gender Equity in Latin America (New York, Garland Publishing).

ECLAC (1995) Regional Programme of Action for the Women of Latin America and the Caribbean, 1995-2001 (Santiago, Economic Commission for Latin American and the Caribbean).

FilgueIRA, C. (1983) To educate or not to educate. Is that the question? CEPAL Review, 21, pp. 56-86.

GEO and REPEM (1999) Education in Motion. Educational watch on gender and education (Montevideo, Gender and Education Office of the International Council for Adult Education and Red de Educacion Popular Entre Mujeres de America Latina y el Caribe).

Gonzalez, R. M. \& Villaescusa, M. E. (1998) Politicas publicas en genero y educacion: analisis del caso Mexicano. Paper presented at the seminar on Seguimiento de las Conferencias Beijing y Hamburgo: Genero, Educacion y Ciudadania. Influencias en Politicas Publicas, Santa Cruz, Bolivia, 22-26 June.

Grindle, M. (1986) State and Countryside Development Policy and Agrarian Politics in Latin America (Baltimore, The Johns Hopkins University Press).

Havelin, J. (1999) Education and campesinas in Nicaragua, 1960-1997, Los Angeles, Center for International Studies, USC, mimeo, April.

Hornberger, N. (1987) Schooltime, classtime, and academic learning time in rural highland Puno, Peru, Anthropology of Education Quarterly, 18, pp. 207-221.

InTERAGENCY COMmission WCEFA (UNDP, UNESCO, UNICEF \& WorLd BANK) (1990) Final Report. World Conference on Education for All: Meeting Basic Learning Needs (Jomtien, Interagency Commission WCEFA).

IGLESIAS, E. (1981) Development and equity: the challenge of the 1980s, CEPAL Review, 1(15), pp. 7-46.

KABEER, N. (1996) Agency, well-being, and inequality: reflections on the gender dimensions of poverty, IDS Bulletin, 27(1), pp. 11-25.

KING, E. \& HiLl, A. (Eds) (1993) Women's Education in Developing Countries. Barriers, benefits, and policies (Baltimore, The Johns Hopkins University Press).

LitTle, A. (1999) Multi-grade teaching: why is it important to take seriously? Paper presented at the Fifth Oxford Conference on Education and Development, 9-13 September.

Longwe, S. (1998) Education for women's empowerment or schooling for women's subordination? Gender and Development, 6(2), pp. 19-26.

Martin, J. (1997) La equidad en el presupuesto publico, CEPAL Review, December, pp. 17-27.

Montero, C. \& Tovar, T. (1999) Agenda Abierta para la Educacion de las Ninas Rurales (Lima, CARE Peru, Instituto de Estudios Peruanos, and Foro Educativo).

Moore, JR, B. (1978) Injustice: the social bases of obedience and revolt (White Plains, NY, M.E. Sharper).

O’Gara, C., Benoliel, S., Sutton, M. \& Tietjen, K. (1998) More, But Not Yet Better. USAID's programs and policies to improve girls' education in developing countries. Draft (Washington, Center for Development Information and Evaluation, USAID), December.

Oxhorn, P. (1998) Social inequality, civil society and the limits of citizenship in Latin America. Paper presented at the annual meeting of the Latin American Studies Association, Chicago, 24-26 September.

Post, D. (1998) Educational inequality in Mexico. Paper presented at the annual Comparative and International Education Society conference, Buffalo, April.

PROMUDEH (2000) Plan Nacional de Igualdad de Oportunidades entre Mujeres y Hombres 2000-2005 (Lima, Ministerio de Promocion de la Mujer y del Desarrollo Humano) [Ministry for the Promotion of Women and Human Development].

PURYEAR, J. (1997) Education in Latin America: problems and challenges (Washington, DC, Inter-American Dialogue).

Rama, G. (1983) Education in Latin America: exclusion or participation, CEPAL Review, 21, pp. 13-38.

Rosemberg, F. (2000) Ambiguities in compensatory policies: a case study from Brazil, in: R. CortinA \& N. P. StromQuist (Eds) Educational Policies for Gender Equity in Latin America (New York, Garland Publishing).

Selbin, E. (1998) Social justice in Latin America. Dilemmas of democracy and revolution. Paper presented at the annual meeting of the Latin American Studies Association, Chicago, 24-26 September. 
Streitmatter, J. (1994) Toward Gender Equity in the Classroom (Albany, State University of New York Press).

Stromquist, N. P., Klees, S. \& Miske, S. (2000) USAID Efforts to expand and improve girls' primary education in Guatemala, in: R. Cortina \& N. P. Stromquist (Eds) Educational Policies for Gender Equity in Latin America (New York, Garland Publishing).

Torres, R. M. (2000) One Decade of Education for All: the challenge ahead (Buenos Aires, International Institute of Educational Planning and UNESCO).

Townsend, J., Zapata, E., Rowlands, J., Alberti, P. \& Mercado, M. (1999) Women and Power: fighting patriarchy and poverty (London and New York, Zed Books).

UNESCO (1998) Statistical Yearbook 1998 (Paris, UNESCO).

World BANK (1993) Human Resources in Latin America and the Caribbean: priorities and action (Washington, DC, The World Bank).

World Education Forum (2000) The Dakar Framework for Action. Education for All: meeting our collective commitments (Dakar, WEF), 26-28 April. 